\title{
Factors Affecting Level of Children Resilience and Teachers' Opinions about Resilience
}

\author{
Sibel Yoleri $(i){ }^{*}$ \\ ${ }^{1}$ İzmir Democracy University, Department of Preschool Education, İzmir, Turkey
}

\section{ARTICLE HISTORY}

Received: Nov. 23, 2019

Revised: Apr. 2, 2020

Accepted: Aug. 12, 2020

\section{KEYWORDS}

Resilience,

Temperament,

Teachers,

Preschool children

\begin{abstract}
This research mainly focuses on two purposes, the first of which is to examine the relationship between the resilience levels of 5-6-year-old preschool children, their temperament, and their ages. The second purpose of the research is to determine the opinions of their teachers on resilience and resilient children, the risk factors that affect the resilience and the protective factors. Accordingly, the mixed- method design was used in the study. The sample in the quantitative part of the study consisted of the parents and teachers of the 151 children enrolled in preschool education under the Usak Provincial Directorate for National Education. Qualitative data were collected from the interviews with 15 preschool teachers. The quantitative data were collected using the "Early Childhood Resilience Scale" and "The Short Temperament Scale for Children". The qualitative data were collected using the "Semi-structured Interview Form" which consists of 4 questions regarding the 15 preschool teachers' opinions on resilience. According to the results, the age and temperament (i.e., persistence and reactivity) were found to be significant predictors of resilience. It was also found that the resilience scores of the children increased with age. The qualitative data were analyzed using descriptive and content analysis methods. The teachers expressed the highest rate of resilience as "being able to struggle", while the characteristics of the children, who have resilience behaviour, were described as "being determined". They expressed the concept of "domestic violence" as a risk factor that may influence resilience, and "personality traits" as the protective factor.
\end{abstract}

\section{INTRODUCTION}

Research indicates that during early childhood, it is important for children to have a good quality of care and opportunities of learning, adequate nutrition, and community support for families, and also to facilitate the positive development of cognitive, social and self-regulation skills. During these years, the roots of competence are established and many of the most important protective systems for human development emerge. These early years hold great promise for interventions to prevent and reduce risk, boost resources, promote competence and build a strong foundation for future development (Masten, Gewirtz, \& Sapienza, 2013). Individuals face with many different situations, changes, positive or negative life events in the 
developmental process and they experience an adaptation process. Various skills and strategies need to be taught as early as possible so that children are prepared for potential adversities and they can make the most of future learning opportunities. The early childhood period is an important stage of life for understanding and promoting resilience. In this process, some individual traits function as the facilitating factors. It is difficult to mention a conventional definition of the concept "resilience", which is referred to in different ways in the literature.

Masten, Best and Garmezy (1990) defined resilience as "individual's having a successful adaptation capacity despite challenging conditions or threats to the development and adaptation of the individual, making efforts to overcome them and ultimately succeeding at". Resilience refers to the ability to overcome challenging situations as well as the ability to be strengthened as a result. Resilience is a developmental and dynamic process (Grotberg, 1995), which is expressed as the ability to recover after the difficulties encountered in individuals' life (Goldstein, \& Brooks, 2005), to come up with good results although they encounter risky situations, to get rid of the negative effects of these situations successfully, and more importantly, to be able to revert back to their previous condition (Luthar, 1991; Luthar, Cicchetti, \& Becker, 2000; Luthar, 2006; Masten, 2001). Individuals with a high level of resilience are, therefore, able to adapt easily to changing conditions, overcome problems more quickly, and produce solutions to problems in greater numbers and variety (Taylor et al., 2013). At this point, the important issue is seen as being aware of the factors supporting the development of resilience.

Resilience, which is described as the ability of children to overcome social, emotional, developmental, economic, and environmental challenges (Goldstein, \& Brooks, 2005), changes depending on innate factors (eg. personality traits such as easy temperament, patience, etc.) and environmental factors (eg. family, school and social environment characteristics) (Masten, \& Powell, 2003). Thus, affective, environmental and social characteristics of an individual influence each other and have a common effect on resilience (Hjemdal, 2007; Ungar, 2011, 2012). In many studies, researchers emphasize the ecological approach. Bronfenbrenner's (1994) theory of ecological systems suggests that a person develops in interconnected environments and multiple ecological levels, affecting the development of the individual both directly and through interactions between ecological levels. The ecological system approach refers to the interactions of internal and external forces affecting the behavior of individuals (Danış, 2006; Masten, 2015; Ungar, 2013). This approach draws attention to a variety of factors that shape children's early experiences and influence their levels of resilience (Bronfenbrenner, 1979). According to this perspective, the capacity of the individual to be resilient arises as a result of the level of interactions between personality and environmental factors (Ungar et al., 2007). For example, children who have the advantage of living in a safe community and loving the home environment have greater access to factors that will enable them to exhibit a high level of resistance in the face of adversity (Bowes, Grace, \& Hodge, 2012).

Definitions linked to resilience and researches have emphasized two concepts: risk factors and protective factors. It is important that both risk factors and protective factors are referred to at an individual and environmental level. Risk factors are factors that trigger, or cause stress which individuals may encounter. The risk factors, particularly for children, include socio-economic variables (low socio-economic background, poverty, etc.), family variables (negative parental attitudes, separation from parents or having a single parent, death of parents, sick parents, etc.), genetic conditions, child abuse/neglect and negative life experiences (terrorism, immigration, war, natural disasters, etc.) (Greene, 2002; Luthar, Cicchetti, \& Becker, 2000; Masten, 2001; Reed-Victor, \& Stronge, 2002).

Approaches and skills against risk factors that reduce the effects of the environmental risk or difficulty experienced by the children or allow them to overcome those and improve healthy 
adaptation are called "protective factors" (Gizir, 2004; Masten, 1994; Sattler, \& Font, 2018). Werner and Smith (1992) indicate that protective factors have a significant impact on child development (cit.: Ersay \& Erdem, 2017). Protective factors may be found at individual, family and community levels (Wright, Masten, \& Narayan, 2013). Protective factors thought to offset the debilitating effects of multiple stress factors in childhood were divided into three categories by Garmezy (1985). This trio of factors has been supported by subsequent studies as well. These factors include; (1) positive temperament, marked self-esteem, ability, and social responsiveness; (2) a supportive family environment that includes a solid relationship with at least one parent; and (3) social support in a non-family environment, such as school or community. In the literature, for example, positive personality traits are listed in the category of individual protective factors (see Smith, \& Prior, 1995). In addition, some factors such as intelligence, problem-solving skills, temperament, self-regulation skills based on temperament, coping skills, and social competence are also defined as protective factors (Afifi, \& MacMillan, 2011; Benzies, \& Mychasiuk, 2009; Lee, \& Stewart, 2013; Masten, Best, \& Garmezy, 1990; Masten, 2001; Oades-Sese, \& Esquivel, 2006). It is important that protective factors outweigh the impact of risk factors that may be exist in children's close surroundings because protective factors can moderate the effects of different risks (Sattler, \& Font, 2018).

Temperament is referred to as one of the individual traits that could increase resilience (Compas et al., 2001; Rutter, 1987). Various definitions of temperament among protective factors have been made in studies about resilience. The temperament is the individual differences (Sanson, \& Rothbart, 1995), which are biologically based, representing the differences in individual's relativity and self-control (Rothbart, \& Bates, 2006), relatively persistent (Sanson, Hemphill, \& Smart, 2004), but may vary depending on the stimuli and expectations' change from the environment. Prior et al. (2011) described the temperament as a 'behavior'. Various temperament traits have been expressed in order to reveal the behavior of individuals. Approach/withdrawal, persistence/patience, adaptability, rhythmicity, activity level, intensity of responses, stimulation threshold, distractibility and attention span are some of them (Akin Sar1, 2018; Grist, \& McCord, 2010; Yağmurlu, \& Kodalak, 2010). Individuals are divided into three groups according to their behaviors they have exhibited since birth, with easy temperament, difficult temperament and slow to warm up temperament. Easy tempered, which is also included among the protective factors, refers to calm, warm-hearted, and cheerful children who can easily adapt to changes. Difficult tempered babies are easy to cry, hard to calm and cannot easily adapt to change. On the other hand, individuals who are slow to warm up tempered are those reacting less negatively compared to difficult tempered children, but sometimes more aggressive (Afifi, \& MacMillan, 2011; Thomas, \& Chess, 1977; Yağmurlu, \& Kodalak, 2010).

It is clear that early childhood is an important time frame for understanding and encouraging, empowering resilience. These early years are important for attempts to prevent and reduce risk, increase resources, increase competence, and build a strong foundation for future development. It is, therefore, necessary to identify risk factors and protective factors in children's lives in order to understand how to develop resilience and to support children. Teachers, as important adults in children's lives, play a significant role in supporting resilience (Hart et al., 2004; Hattie, \& Gan, 2011). Children, as role models, when learning about personal feelings, make decisions, share their thoughts, and can help solve problems. (Nolan, Taket, \& Stagnetti, 2014). Considering previous studies, although the crucial role of teachers in promoting resilience is highly stated, there are limited studies about preschool teachers' opinions about resilience (Brooks, 2006; Gilligan, 2000; Miljevic-Riđički, Bouillet, \& Cefai, 2013).

It is thought that it is important to examine protective factors that support the resilience in the preschool period in order that children can adapt to the challenging and stressful situations they 
face in their lives. The aim of this study is to determine the predictability of preschool children's age and their temperament traits on resilience. Secondly, it is to evaluate the teachers' opinions and knowledge about being resilient which is an important element in the development and support of resilience. In order to achieve these objectives, the research seeks to answers the following questions:

Is there a relationship between preschool children's resilience and temperament traits and their ages?

Do the age and temperament traits of preschool children measure children's resilience?

What is the knowledge level of preschool children's teachers about resilience, what are their opinions on characteristics of resilient children, risk factors that can negatively affect children's lives and how to protect them from these factors?

\section{METHOD}

This section includes research design, sampling study group, data collection tools, data collection and data analysis.

\subsection{Research design of the study}

In this study, mixed-method research design that combines both quantitative and qualitative patterns was utilized. Mixed method research allows the researcher to combine both qualitative and quantitative methods, approaches and concepts in a study or consecutive studies and thus to better understand and explain the problems (Büyüköztürk et al., 2011; Creswell, 2013). If researchers want to use a mixed method, they should first determine what the purpose of the research is and then decide the order to collect the quantitative and qualitative data (Creswell, 2013). They will then determine the methodology to offer more space, integrate the data collected by the two approaches and eventually establish a theoretical point of view that will shape the basis of the study (Creswell, 2013; Yıldırım \& Şimşek, 2013).

Several mixed-methods have been developed in terms of research designs: consecutive descriptive, consecutive discovery, sequential converter, concurrent triangulation, concurrent nested and concurrent converter (Creswell, Plano Clark, Gutmann, \& Hanson, 2003; Hanson et al., 2005; Morse, 2003). This study has used a concurrent nested design, in which both qualitative and quantitative data are collected and analyzed simultaneously. Although the quantitative and qualitative data are collected at the same time in the concurrent nested pattern, either quantitative data or qualitative data take up a larger part of the study (Creswell, 2013). Data analysis was conducted separately, and data were combined during interpretation. The data obtained by the quantitative method (Short Temperament Scale for Children, Early Childhood Resilience Scale) were higher and were supported by qualitative method (voice/video recording, semi-structured interview form).

\subsection{Participants}

As specified by Kemper et al. (2003), the Sequential Quantitative-Qualitative technique is the most commonly used one in the literature. In many studies conducted with this technique, the final sample used in the quantitative stage is employed as a determinant for sampling in the later qualitative stage.

In mixed-method research, sampling refers to sampling and environment selection processes and methods for each of the quantitative and qualitative research (Creswell, 2013). Due to the mixed method, the study group selection was carried out in two stages as both quantitative and qualitative data collection methods were used together.

For the quantitative part of the study, the parents and children's teachers who work in kindergartens in Uşak city center are the target population of the study. The sample consists of 
the parents and teachers of the children of 5 kindergartens in Uşak city center, who are thought to represent the reachable population and randomly selected from reachable population. During the formation of the sample study group, it was taken into consideration that all children showed a normal development. $49.7 \%(n=75)$ of the children were female and $50.3 \%(n=76)$ were male. $35.8 \%(n=54)$ of the children, who participated in the study, were 5 years old and $64.2 \%$ $(n=97)$ were 6 years old.

Fifteen teachers took part in the qualitative aspect of the study. Participants were the preschool teachers who were selected by means of purposive sampling method within the scope of the sample, where quantitative data were obtained. Most qualitative researches do not make a limitation by giving certain numbers; however, 20 to 30 participants in the theory-building studies; in a case study, 4 to 10 participants can be used (Creswell, 2013). 15 of the participating teachers were 20-40 years old. Twelve of these teachers were four-year faculty graduates. Three teachers had an associate degree. Nine of the teachers had 10-15 years of professional experience, four of them had 5-10 years and two of them had 2-3 years. The average number of children in their class was 24 .

\subsection{Instruments}

Under this heading, the tools employed to collect quantitative and qualitative data and the purpose of use of these tools are given.

\subsubsection{Quantitative Data Collection Tools Used in Research}

In the study, the Demographic Information Form, Early Childhood Resilience Scale and Short Temperament Scale for Children were employed to collect quantitative data.

\subsubsection{Demographic information form}

In the form where questions related to personal details were included, the age and the gender of the child, the age and the gender of the parent, their educational status, economic status and the number of children were asked. In the form prepared for teachers, questions about the gender, age, education level, professional experience of the teacher and the number of children in their class were included.

\subsubsection{Early childhood resilience scale}

The first form of the scale developed by E. Ersay (individual interview, March 28, 2018) consisted of 51 items. In later analysis, items with a factor load value of less than 0.45 and a factor load value of less than 0.10 (12 items) were excluded from the scale. After the analysis repeated in this direction, it was determined that 39 items showed a single factor structure. The alpha coefficient of the Cronbach's answers given to the 39 items in the final form of the scale was calculated as 0.977 . This scale was filled by the teachers for each child selected in compliance with the purpose of the research. To determine the reliability of responses to scale items, the alpha coefficient of Cronbach was estimated from the internal coefficients of consistency, and the alpha coefficient of the Cronbach was defined as 0.942 .

\subsubsection{The Short temperament scale for children}

This scale (Prior, Sanson, \& Oberklaid, 1989) was developed to determine children's temperament characteristics. The scale consists of 30 items with four subscales. Sample items for dimensions were: Reactivity (e.g. 'When upset or annoyed with a task, my child throws it down, cries slams doors, etc.'), Persistence (e.g. "My child is unwilling to leave a game or activity that he/she has not completed"), Rhythmicity (e.g. "My child would like to grab a bite to eat almost at the same time everyday"), Approach/withdrawal (e.g. "My child is shy when first meeting new children"). The internal consistency scores for the original version of the scale were 0.66 for approach, 0.75 for inflexibility/reactivity, 0.75 for persistence, and 0.51 for 
rhythmicity (Prior, Sanson, \& Oberklaid, 1989). In Yağmurlu and Sanson's study (2009) internal consistency was .80 for Approach/Withdrawal, .77 for Reactivity, .48 for Rhythmicity and .76 for Persistence. In this current study, the Cronbach's alpha coefficient scores for Approach subscale was .64, .68 for Reactivity, .65 for Persistence, and .54 for Rhythmicity.

\subsubsection{Qualitative Data Collection Tool Used in Research}

In the qualitative aspect of the study, a case study of qualitative research methods was employed. The interviews is one of the most frequently used data collection tools in qualitative research. Various interview techniques are used in qualitative research (Yıldırım, \& Şimşek, 2013). In this study, semi-structured interview technique was used because of the aim of determining the opinions and practices of teachers about resilience and for the flexibility provided by the method.

\subsubsection{Semi-Structured interview form}

A semi-structured interview form was prepared to complete the mixed method research, and preschool teachers were asked to share their views on what resilience is, what resilient children's characteristics are, what the risk and protective factors can be. In the preparation of the interview questions developed by the researchers, attention was given to the principles in that to be easy to understand and not to be multidimensional, and that it should not direct the interviewer (Yıldırım \& Şimşek, 2013). In the preparation of the form used in the study, the opinions of two faculty members, who are experts in the field having research on qualitative studies, and the information in the related literature were employed. The prepared draft form was submitted to the opinion of two different faculty members, who had studies on preschool education, before performing the trial practice. In order to test the comprehensibility and conformity of the questions with the purpose, the preliminary practice was carried out with two teachers outside the study group. As a result of these interviews, it was determined that there was no problem in terms of comprehensibility and started to work with the working group.

\subsection{Procedure}

Under this heading, the collection process of quantitative and qualitative data is included.

\subsubsection{Quantitative Data Collection and Research Process}

The temperament traits of the children were filled by the mothers of the children in the sample group. The Early Childhood Resilience Scale was filled by the teachers of the same children.

In the process of collecting quantitative data, firstly permission was obtained from Uşak Provincial Directorate of National Education. Then, in line with the permission, teachers and managers were informed about the study and it was decided to reach parents with training schools and to take advantage of parents' meetings held within the scope of family participating activities. At the end of the meetings, the parents were informed about the scope, purpose and measurement tools of the study and it was explained that the data obtained from the study would be used only within the scope of scientific research, in which their personal details would be kept confidential. Data collection tools did not contain any personal information about either a mother or a child. Only parents who volunteered to participate in the study were included in the study. The measurement tool was sent to 250 families in 5 preschools in Uşak city center, and the total number of completed items was 165 at the end of the data collection process. As a result of the analysis of the collected data, 14 data were excluded due to the lack of information and calculations were made with 151 data sets. In order to make a reliable interpretation, return rate of the measurement tool is recommended to be over 70-80\% (Büyüköztürk et al., 2011). It is seen that the ratio in the study is sufficient in this sense. 


\subsubsection{Collection of Qualitative Data}

Semi-structured interview form was conducted on 15 volunteer participants among the teachers participating in the research. The interviews lasted approximately 20-30 minutes and were conducted in a relatively quiet area of the school. The interview started with the introduction of interviewer before the questions, the subject of the research was reminded, and its purpose was stated. Then some brifed information was given about the principles of confidentiality. The responses of the teachers, who accepted, were recorded with a voice recorder. The answers to those who did not approve were recorded in writing. In the interview, open-ended and easy-tounderstand questions were asked in a certain order.

\subsection{Data Analysis}

The research study continued from September 2018 to November 2018 for the entire process of data collection. Both quantitative and qualitative data are analyzed at the same time. As in a concurrent qualitative-nested quantitative study, the quantitative data are the primary data resource whereas the qualitative data are supportive of the explanations.

\subsubsection{Analysis of Quantitative Data}

The quantitative aspect of the study was carried out based on the screening model. The screening model, which is one of the descriptive research types and which uses questionnaires or scales as data collection tools, enables the researcher to describe the current situation. In the screening model, participants in a sample from a population are presented with a pre-determined set of questions (Büyüköztürk et al., 2011; Karasar, 2012). If the sample number is less than 30 , the Shapiro-Wilk normality test is applied; if it is 30 and more, the Kolmogorov-Smirnov normality test is applied (Büyüköztürk, 2015). Kolmogorov-Smirnov normality test was applied since a total of 151 scales were included in the analysis. As a result of the KolmogorovSmirnov normality test, a normal distribution of data was observed.

The correlation coefficient was investigated to determine the relationship between the resilience levels of children and their ages and temperament traits (approach/withdrawal, persistence, rhythmicity, reactivity). The correlation coefficient is used to find and interpret the amount of the relationship between the two variables (Büyüköztürk, 2015). Multiple Regression Analysis was employed to determine whether their ages and temperament traits predicted their resilience and if any, to calculate the predictive power.

\subsubsection{Analysis of Qualitative Data}

For the analysis of the qualitative data obtained from the research, the content analysis was applied on the qualitative data. The main purpose of the content analysis is to reach the concepts and relations that can explain the qualiatively collected data. Within the context of content analysis, the stages such as categorization of the data, finding the themes, arranging and defining the data according to codes and themes, and interpreting the findings follow each other (Yıldırım, \& Şimşek 2013). Firstly, the interviews were transformed into a written form by the researchers on computer and tables were formed based on the opinions of the participants. The content analysis continued by reviewing the written data. In the data examined, remarkable and important aspects were determined, followingly codes and then categories were obtained. The code and categories were then made clear by comparing the code and categories produced separately. In order to reflect the opinions of teachers, direct quotations were made from the statements of the teachers. The opinions of the participants were transferred on the basis of confidentiality and coded without giving their names. According to this, teachers were coded as "T" and each participant was given a number as "T1-T15" next to their code. 
At the end of the research, two child development specialists, two preschool education specialists and a measurement and evaluation specialist examined the conformity of the responses given, to the themes obtained, during the Validity Reliability Determination Phase. In order to determine the reliability of the study, "consensus" and "dissidence" numbers were determined and used to provide the consistency of judgement across various viewers (interrater reliability) suggested by Miles and Huberman's (1994). In qualitative studies, a significant reliability is obtained in cases where the calculation is $70 \%$ or higher. Since the reliability of the coding is determined as $82 \%$, it is accepted that the study is reliable (Miles, Huberman, \& Saldana, 2014).

\section{RESULT / FINDINGS}

\subsection{Analysis of quantitative data}

In the study, the resilience of children was accepted as dependent variable and this variable was tested with multiple regression model to determine how this variable predicted the age and temperament traits of the child. In the research, sub-factors of age and temperament were evaluated together, and progressive multiple regression model was preferred. Firstly, the assumptions required to make the multi-connection model were evaluated. Assuming that the tolerance values are not less than .05 with the assumption that all independent variables are not above .70, the hypotheses that the VIF value is below 10 and that there is no autocorrelation, and that the variables are usually distributed, one by one is evaluated, and the hypothesis that there are no multiple correlations assured.

Correlations related to the relationship between resilience levels, age of children and temperament traits, mean and standard deviation values are shown in Table 1.

Table 1. Arithmetic Mean, Standard Deviation and Correlation Coefficients of Variables $(N=151)$

\begin{tabular}{lcccccc}
\hline & 1 & 2 & 3 & 4 & 5 & 6 \\
\hline Resilience & 1 & .01 & $.34^{* *}$ & .12 & $-.26^{* *}$ & $.31^{* *}$ \\
Approach/Withdrawal & & 1 & .01 & -.04 & -.07 & -.00 \\
Persistence & & & 1 & $.19^{* *}$ & $-.24^{* *}$ & .09 \\
Rhythmicity & & & & 1 & $-.19^{*}$ & .09 \\
Reactivity & & & & & 1 & .01 \\
Child age & 162.46 & 26.53 & 27.95 & 28.92 & 26.57 & 1.64 \\
$\bar{X}:$ & 25.86 & 6.25 & 6.09 & 5.41 & 7.32 & .48 \\
$S s$ & & & & & &
\end{tabular}

As seen in Table 1, the correlation analysis revealed no correlation between resilience and being approach/withdrawal and rhythmicity, which are among the temperament traits $(p>.05)$. On the other hand, it was observed that there was a statistically significant positive correlation between persistence and temperament traits and resilience $(r=.34, p<.01)$ and statistically significant negative correlation with reactivity $(r=-.28, p<.05)$. When Table 1 is examined, it is observed that there is a statistically significant positive correlation between resilience and age of the child $(r=.31, p<.01)$.

In the second stage of the analysis of quantitative data, progressive multiple regression analysis was applied to determine whether the temperament traits and the children ages predicted the level of children's resilience, if so, to what extent. The results of the progressive multiple regression analysis are given in Table 2. 
Table 2. Results of progressive multivariate regression analyses

\begin{tabular}{lcccccccc}
\hline & $\beta$ & $\mathrm{SHb}$ & $\beta$ & $\mathrm{t}$ & $\mathrm{F}$ & $\mathrm{R}$ & $\mathrm{R}^{2}$ & $\Delta \mathrm{R}^{2}$ \\
\hline (Constant) & 121.60 & 9.33 & & $13.024^{* *}$ & 20.057 & .344 & .119 & .113 \\
Persistence & 1.46 & .32 & .344 & $4.478^{* *}$ & & & & \\
(Constant) & 99.42 & 10.64 & & $9.342^{* *}$ & & & & \\
Persistence & 1.36 & .31 & .320 & $4.339^{* *}$ & & .445 & .198 & .187 \\
Child age & 15.23 & 3.97 & .283 & $3.834^{* *}$ & 18.301 & & & \\
(Constant) & 122.84 & 13.71 & & $8.957^{* *}$ & & .484 & .234 & .219 \\
Persistence & 1.15 & .31 & .272 & $3.648^{* *}$ & & & & \\
Child age & 15.62 & 3.89 & .291 & $4.009^{* *}$ & 14.997 & & & \\
Reactivity & -.69 & .26 & -.196 & $2.631^{* *}$ & & & & \\
\hline
\end{tabular}

Dependent Variable: Resilience, ${ }^{* *} p<0.01$

In Table 2, when the $\mathrm{R}^{2}$ values were examined, it was observed that persistence scores, one of the temperament traits, alone accounted for $12 \%$ of the variance $[\mathrm{F}(1,149): 20.057 ; p<.01]$. Then, when the age of the child was added, it was seen that the persistence and child age explained $20 \%$ of the total variance $[\mathrm{F}(1,148): 18.301 ; p<.01]$. In the final stage, the reactivity score, one of the temperament traits, was added, and they were observed to account for $22 \%$ of the variance. According to the t-test results for the independent variables, the age of the child $(\beta=.291 ; p<.01)$ is the strongest predictor of resilience, and it was followed by persistence, one of the temperament traits $(\beta=.272 ; p<.01)$ and reactivity, another one of the temperament traits, $(\beta=-.196 ; p<.01)$. In addition, regression equation shows that the reactivity, one of the temperament traits, expressed negatively the resilience levels, on the contrary, it reflected significantly positively the persistence, one of the temperament traits, and the age of the child. The relationship between resilience and temperament traits (the persistence and the reactivity) and child's age was shown in Figure 1.
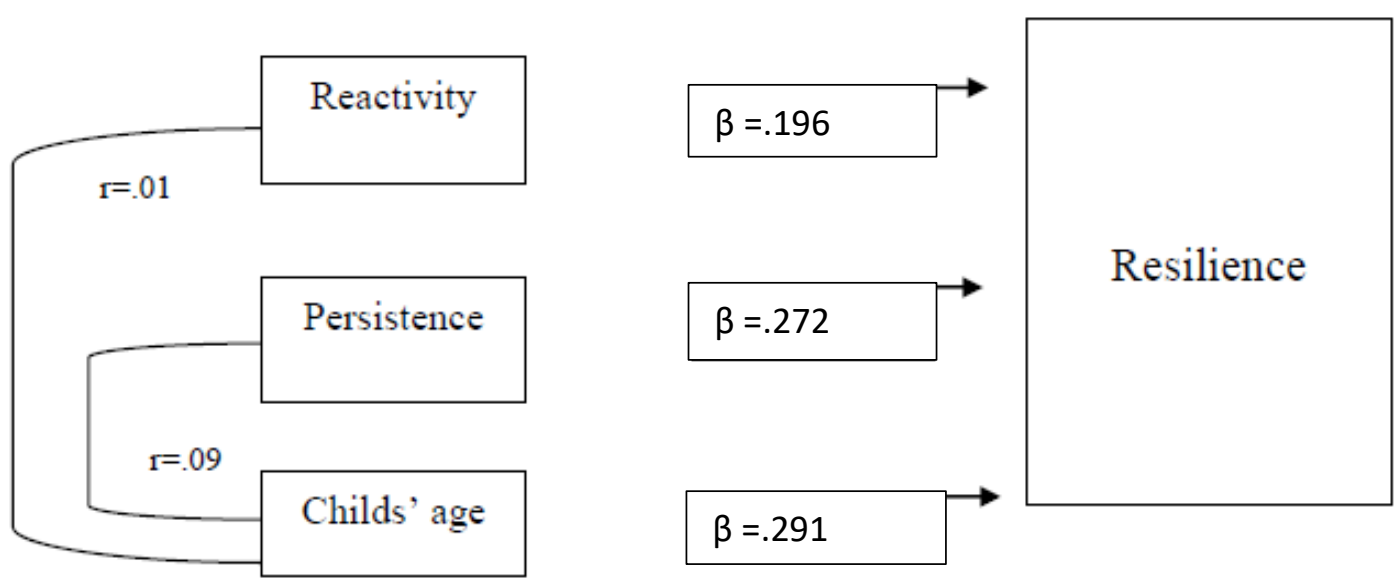

Figure 1. Model showing the Relation between Resilience and the Variables of "Persistence" and "Reactivity" of Temperament Traits and "the Child's Age"

\subsection{Analysis of qualitative data}

In Table 3 the frequency (f) according to the responses given by the preschool teachers, who took part in the research, to the question "What is resilience?". According to the opinions, most ability to struggle $(f=11)$ was expressed. The teachers' answers to the question included the following:

(T2) "...despite the difficult conditions not to self-surrender..."

(T3) "...resistance to positive or negative situations..." 
(T4) "...to struggle with the difficulties in achieving the goal..."

(T11) "...to struggle, not to give up..."

Table 3. Teachers' Opinions on the Concept of "Resilience"

\begin{tabular}{lll}
\hline Themes: & $\mathrm{f}$ \\
\hline \multirow{3}{*}{ Codes } & Ability to struggle & 11 \\
& Ability to recover one-self & 8 \\
& Ability to resist difficulties & 5 \\
Ability to own manage emotions & 5 \\
Not to self-surrender & 2 \\
Determination & 2 \\
\hline
\end{tabular}

Table 4. Teachers' Opinions on Resilient Children's Traits

\begin{tabular}{|c|c|c|}
\hline \multicolumn{2}{|c|}{ Themes: Resilient Children's Traits } & \multirow{2}{*}{$\begin{array}{l}\mathrm{f} \\
15\end{array}$} \\
\hline & To be determined & \\
\hline \multirow[t]{7}{*}{ Codes } & To be able to direct their attention to different tasks & 12 \\
\hline & Ambition & 11 \\
\hline & Obstinacy & 7 \\
\hline & To have faith in succeeding & 7 \\
\hline & To be persistent & 7 \\
\hline & To be curious & 5 \\
\hline & To be patient, to try till end & 5 \\
\hline
\end{tabular}

Table 4 indicates the frequencies (f) of the features expressed by teachers with regard to the features of resilient children. It has been stated that it is the most being determined $(f=15)$ of the opinions. Later, teachers were able to direct the attention of resilient children to different activities $(f=12)$, ambition ( $f=11)$, obstinacy $(f=7)$, believing that they could succeed $(f=7)$, be persistent $(\mathrm{f}=7)$, be curious ( $\mathrm{f}=5)$ and stating that they were children who were patient and carried out the activity to the end $(\mathrm{f}=5)$. Some of the participants' opinions are as follows;

(T1) "...to be able to finish a task without getting bored, without giving up..."

(T3) "...they do not give up, they try anyway to achieve what they want..."

(T8) "...works hard to achieve what he/she wants..."

(T15) "...they are confident children..."

Table 5. Teachers' Opinions on Risk Factors

\begin{tabular}{|c|c|c|}
\hline \multicolumn{2}{|c|}{ Themes: Risk Factors } & $\mathrm{f}$ \\
\hline \multicolumn{2}{|c|}{ Domestic violence } & \\
\hline \multirow[t]{5}{*}{ Codes } & Abuse & 15 \\
\hline & Negative financial conditions (eg. poverty) & $\begin{array}{c}15 \\
9\end{array}$ \\
\hline & Parents' attitudes & 9 \\
\hline & Death of one of the family members & 3 \\
\hline & Technology such as Internet, computer etc. & 3 \\
\hline
\end{tabular}

As seen in Table 5, in the study, teachers defined mostly "domestic violence" among the risk factors that may cause resilience. In addition, the risk factors stated by the teachers are abuse $(f=15)$, negative financial conditions $(f=9)$, parental attitudes $(f=9)$, death of one of the family 
members $(\mathrm{f}=3)$ and the effect of technological devices such as the Internet and computer $(\mathrm{f}=$ $3)$. Some of the participants' opinions are as follows;

(T8) "...domestic violence is the most important risk factor in my opinion..."

(T10) "...children who experienced mother-father death, or their separation are under the risk..."

(T12) "...nowadays, I think the computer, internet, tv negatively affect children of all ages..."

Table 6. Teachers' Opinions on Protective Factors

\begin{tabular}{llc}
\hline Themes: Protective Factors & $\mathrm{f}$ \\
\hline \multirow{2}{*}{ Codes } & Personality traits & 13 \\
& Family support & 8 \\
& Teachers' approach & 5 \\
& School-family cooperation & 5 \\
\hline
\end{tabular}

In Table 6, teachers mostly stated "personality traits" among the protective factors in the lives of individuals. Some of the participants' opinions are as follow;

(T4) "...the support of the family is very important..."

(T5) "...not only the family but also the support of other family elders (such as grandparents is very important..."

(T8) "...approach of teachers in school..."

(T14) "...some child personality traits (eg. temperament, some children very impatient) ..."

\section{DISCUSSION and CONCLUSION}

The aim of this study was to investigate the relationship between the resilience traits and age and temperament traits of the 5-6-year-old children having preschool education and to investigate the perceptions of preschool teachers' resilience. For this purpose, data were collected from mothers of children having preschool education and from preschool teachers.

In the quantitative aspect of the study, a positive correlation was found between the resilience levels of the children and the children's age and "persistence" among temperament traits, and a negative correlation between "reactivity" among temperament traits. In addition, it was determined that the child's age and persistence and reactivity dimensions of the temperament were predictive variables of child resilience.

Children with persistence temperament traits have the ability to concentrate on a task and organize it. Therefore, these children can develop a positive and optimistic point of view for the future. This ability can help them to cope with negative emotions and positively affect resilience. A significant correlation was found between persistence temperament trait and children's resilience levels (Hutchinson, Stuart, \& Pretorius, 2010; Bayındır, Önder, \& Balaban Dağal, 2016). However, the results of a study conducted in Turkey show that persistence and reactivity among temperament trait are associated with preschool children's resilience levels (Önder, Balaban Dağal, \& Bayındır, 2018). Oades-Sese and Esquivel (2006) studied on the resilience with 207 Afro-American children in 50 economically disadvantaged early childhood classes. Cognitive ability, temperament, autonomy and language skills were found to be protective factors in their studies (Ersay \& Erdem, 2017). On the other hand, reactivity refers to being ready to respond to a particular stimulus or event, and this trait being higher makes it difficult to control emotion regulation and behavior in children. Studies show that children with high reactivity experience more externalization problems (Kochanska \& Knaack, 2003; Oldehinkel et. al., 2004; Spinrad et al., 2007; Yoleri, 2014). As a finding of the analysis, 
reactivity as the characteristic of the children's personality decreases, resilience scores decrease, and resilience scores improve if they decrease. This result underpins abstract theories and literature analyses. Reactivity temperament trait was found to be associated with the resilience levels of children (Cumberland-Li, Eisenberg, \& Reiser, 2004; Eisenberg et al., 2004; Eisenberg, Spinrad, \& Morris, 2002). Similarly, in the literature, individuals with low resilience levels show more problems with inward and outward orientation (Eisenberg, Spinrad, \& Morris, 2002; Eisenberg et al., 2010; Kabasakal \& Arslan, 2014; Kim \& Im, 2014).

As a result of the research, the age of the children was found as a predictor of the resilience of children. When the literature about resilience-age correlation is examined, different results are revealed. Review showed typically that older generation has higher resilience (Campbell-Sills et al., 2009; Herrman et al., 2011; Lundman et al., 2007). It has been emphasized that children at little ages are more and easily vulnerable to all risk factors compared to adolescents and youngsters (Luthar, 1999; as cited in Gizir, 2007). A study by Bayındır et al. (2017) found that 6-year-old children had higher emotion regulation skills than 5-year-olds. According to the teacher evaluation, in a study that examined the resilience levels of preschool children, teachers stated that children's resilience levels of seven-year-old children were higher than the six-yearolds and the five-year-olds were higher than the four-year-olds (Miljević-Riđički, Plantak, \& Bouillet, 2017). On the other hand, the findings of this study differ from previous research findings showing that resilience does not change according to age. In the study conducted by Balaban Dağal and Bayındır (2018), a statistically significant result was not found when the resilience level of the children was evaluated in terms of their ages. In another study conducted by Metin (2010), it was indicated that the age did not predict the emotion regulation skill in children of 3-6 age group. In a meta-analysis study, there was no increase in resilience scores as children's ages increased (Nasvytiene, Lazdauskas, \& Leonavičiene, 2012).

In the qualitative dimension of the research, in the interviews with the preschool teachers, the questions of "What is resilience?", "What are the characteristics of resilient children?", "What are the risk factors on children and protective factors of resilience?" were asked. In line with these headings, the related themes revealed. Teachers expressed the concepts of ability to struggle $(n=11)$, self-recovery $(n=8)$ regarding the concept of resilience. These statements were followed by the ability to resist difficulties $(n=5)$, ability to own manage emotions $(n=$ $5)$, not to self-surrender $(n=2)$, and determination $(n=2)$. The results of various studies have shown that individuals with high level of resilience are individuals with high levels of selfsufficiency, ability to adapt to changing conditions, ability to change behavior when needed, and problem-solving skills (Taylor et al., 2013). In this sense, the teachers' thoughts on the definition of infidelity are consistent with the literature. In relation to the characteristics of resilient children, teachers stated as to be stable $(n=15)$, able to direct their attention on different tasks $(\mathrm{n}=12)$, ambition $(\mathrm{n}=11)$, obstinacy, to have faith in succeeding and to be persistent $(n=7)$, to be curious and behave patiently $(n=5)$. Their opinions on risk factors included domestic violence $(n=15)$ and abuse $(n=15)$, negative financial conditions $(n=9)$, parental attitudes $(\mathrm{n}=9)$, death of one of the family members, and the internet, computer, and so on $(n=3)$. Personality traits $(n=13)$ were the first in terms of protective factors in children's lives against risk factors, while it was followed by family support $(\mathrm{n}=8)$, teachers' approach $(\mathrm{n}$ $=5)$ and school-family cooperation $(n=5)$. Preschool teachers, as the first teacher of children, have a unique opportunity to create a positive effect on the lives of children in preschool classrooms with the idea that every moment of the day is an important moment to increase the resilience of children. Research has also shown that teachers offer positive role models in the lives of flexible children (Cairone, \& Mackrain, 2012). Therefore, it is very important to discover the thoughts of teachers about what this phenomenon of resilience means. Ogelman (2015) reveals the relationship between the level of love and warmth of mothers and fathers and the children's resilience. As the level of love and warmth of the parents' increases, the 
children's resilience increases. Then, the absence of violence in the family, positive behavior in the family, the family environment, the positive perspective of the family events, harmony within the family, raising awareness of the family, and the characteristics of educated parents are in the opinions. In a study by Oswald, Johnson, and Howard (2003), teachers were asked about the factors affecting the development of resilience in students. As a result of the research, the teachers stated that the students' personal inclinations and character traits were the most effective factor in the development of resilience. Green, Oswald, and Spears (2007) asked 14 teachers how they defined resilience and what practices they carried out to support the development of resilience in children. At the end of the study, it was determined that most of the teachers had no accurate information about the resilience and the characteristics of the resilient children. In addition, it was seen that teachers did not consider the concept of risk when explaining the resilience. In the study conducted by Miller-Lewis et al., (2013), they collected information from families and teachers of 485 children between 3-5-years old. It was tried to determine the internal and external forces of the children which can be seen as the protector against the risks. Internal strengths include self-sufficiency, self-esteem, and self-control, while external strengths include relationships between parents and teachers, socio-economic status, family relationships, and stressful life events. In a qualitative study by Miljevic-Riđički, Bouillet, \& Cefai (2013), preschool teachers working in Croatian preschools and families were asked questions about resilience and the factors they thought were important for improving children's resilience. The teachers defined the characteristics of the resilient child as self-confident, emotionally mature children. Resnick and Taliaferro (2011) stated that strengthening protective factors could be provided by teachers. Sun and Stewart (2007) stated that school support is important, while Benard (2004) states that teachers have the potential to increase resilience in children through a classroom environment in which children's safety and love and belonging needs are met.

Understanding how children and adolescents growing with the pressure of stressful life experiences will endure of remaining given all the adverse consequences that affect their survival can shed more light on prevention measures for other children and adolescents at comparable risk. Studies have shown that resilience is a personality trait to learn and develop (Bonanno, 2004; Masten, 2001). In this sense, early intervention programs can improve the resilience of children in preschools.

In future studies, longitudinal studies can be suggested to determine the factors affecting the resilience of individuals of different age groups. Moreover, a study on cultural protective factors can be planned.

It would be useful to increase the knowledge about resilience of teachers, who have an important role among the external support systems that increase resilience and help people to overcome the difficulties and to inform them about how they can help when they encounter children who have experienced different risks in their classes by giving training about risk factors.

There are some limitations in this study. Information on resilience was obtained only from teachers. A research on family expectations of resilience is scheduled for the next phase of the study. Another limitation of the study is that the data collected reflect only a cross-section of the time when the data collected. Data on the age and temperament traits of children and their resilience levels can be discussed in detail in longitudinal studies.

\section{Declaration of Conflicting Interests and Ethics}

The authors declare no conflict of interest. This research study complies with research publishing ethics. The scientific and legal responsibility for manuscripts published in IJATE belongs to the author(s). 


\section{ORCID}

Sibel Yoleri (i) https://orcid.org/0000-0002-7802-2352

\section{REFERENCES}

Afifi, T.O., \& MacMillan, H. (2011). Resilience following child maltreatment: A review of protective factors. Canadian Journal of Psychiatry, 56(5), 266-272.

Akın Sar1, B. (2018). Temperament features and it's impacts on development. Child PsychiatrySpecial Topics, 4(1), 5-9.

Bayındır, D., Önder, A., \& Balaban Dağal, A. (2016). Temperament and resiliency as predictor factors of preschoolers' school readiness. X. European Conference on Social and Behavioral Science, Sarajevo, Bosnia-Herzegovina, 19-22 May 2016.

Bayındır, D., Güven, G., Sezer, T., Akşin-Yavuz, E., \& Yılmaz, E. (2017). The relationship between maternal acceptance-rejection levels and preschoolers' social competence and emotion regulation skills. Journal of Education and Learning, 6(2), 305-316.

Benard, B. (2004). Resiliency: What we have learned. San Francisco, CA: WestEd Regional Educational Laboratory.

Benzies, K., \& Mychasiuk, R. (2009). Fostering family resiliency: A review of the key protective factors. Child \& Family Social Work, 14(1), 103-114.

Bonanno, G.A. (2004). Loss, trauma, and human resilience: Have we underestimated the human capacity to thrive after extremely aversive events? American Psychologist, 59(1), 20-28.

Bowes, J., Grace, R., \& Hodge, K. (2012). Children, families and communities: Contexts and consequences. South Melbourne: Oxford University Press.

Brooks, J.E. (2006). Strengthening resilience in children and youths: Maxi-mizing opportunities through the schools. Children and Schools, 28, 69-76.

Bronfenbrenner, U. (1979). The ecology of human development: Experiments by design and nature. Cambridge, MA: Harvard University Press.

Büyüköztürk, Ş., Kılıç Çakmak, E., Akgün, Ö.E., Karadeniz, Ş., \& Demirel, F. (2011). Bilimsel araştırma yöntemleri. Ankara: Pegem Yayınları.

Büyüköztürk, Ş. (2015). Sosyal bilimler için veri analizi. Ankara: Pegem Yayınları.

Cairone, K.B., \& Mackrain, M. (2012). Promoting resilience in preschoolers: A strategy guide for early childhood professionals (2nd ed.). Villanova, PA: Devereux Foundation.

Campbell-Sills, L., Forde, D.R., \& Stein, M.B. (2009). Demographic and childhood environmental predictors of resilience in a community sample. Journal of Psychiatric Research, 43(12), 1007-1012.

Compas, B.E., Connor-Smith, J.K., Saltzman, H., Thomsen, A.H., \& Wadsworth, M.E. (2001). Coping with stress during childhood and adolescence: problems, progress, and potential in theory and research. Psychological Bulletin, 127(1), 87-127.

Creswell, J.W., Plano Clark, V. L., Gutmann, M., \& Hanson, W. (2003). Advanced mixed methods research designs. In A. Tashakkori, \& C. Teddlie (Ed.), Handbook of mixed methods in social and behavioural research (pp. 209-240). Thousand Oaks, CA: Sage.

Creswell, J.W. (2013). Research design qualitative, quantitative, and mixed methods approaches (4th ed.). London: Sage Publications Inc.

Cumberland-Li, A., Eisenberg, N., \& Reiser, M. (2004). Relations of young children's agreeableness and resiliency to effortful control and impulsivity. Social Development, 13(2), 193-212.

Dağal, A.B., \& Bayındır, D. (2018). The investigation of the level of ego resilience of preschool children. Journal of Early Childhood Studies, 2(1), 132-150.

Danış, M.Z. (2006). Davranış bilimlerinde ekolojik sistem yaklaşımı. Aile ve Toplum, 3(9), 4553. 
Eisenberg, N., Spinrad, T.L., \& Morris, A.S. (2002). Regulation, resiliency, and quality of social functioning. Self and Identity, 1(2), 121-128.

Eisenberg, N., Spinrad, T.L., Fabes, R.A., Reiser, M., Cumberland, A., Shepard, SA., Valiente, C., et al. (2004). The relations of effortful control and impulsivity to children's resiliency and adjustment. Child Development, 75(1), 25-46.

Eisenberg, N., Haugen, Rg., Spinrad, T.L., Hofer, C., Chassin, L., \& Zhou, Q., et al. (2010). Relations of temperament to maladjustment and ego resiliency in at-risk children. Social Development, 19(3), 577-600.

Ersay, E., \& Erdem, E. (2017). Okul öncesi eğitime devam eden 4-5 yaşındaki çocukların yılmazlık özellikleri ve yılmazlığı destekleyici faktörlerin incelenmesi (Unpublished masters thesis). Gazi Üniversitesi, Eğitim Bilimleri Enstitüsü, Ankara.

Gilligan, R. (2000). Adversity, resilience and young people: The protective value of positive school and spare time experiences. Children and Society, 14, 37-47.

Gizir, C.A. (2004). Academic resilience: An Investigation of protective factors contributing to the academic achievement of eighth grade students in poverty (Unpublished Doctoral Thesis), Middle East Technical University, Ankara.

Gizir, C.A. (2007). A literature review of studies on resilience, risk, and protective factors. Turkish Psychological Counseling and Guidance Journal, III (28),113-128.

Goldsmith, H.H., Buss, A.H., Plomin, R., Rothbart, M.K., Thomas, A., \& Chess, S. (1987). What is temperament? Four approaches. Child Development, 58, 505- 529.

Goldstein, S., \& Brooks, R.B. (2005). Why study resilience. In S. Goldstein, \& R.B. Brooks (Eds), Handbook of resilience in children (pp. 3-15). NY: Springer.

Greene, R.R. (Ed.). (2002). Resiliency: An integrated approach to practice, policy, and research. Washington, DC: National Association of Social Workers Press.

Green, D., Oswald, M., \& Spears, B. (2007). Teachers' (mis) understandings of resilience. International Education Journal, 8(2), 133-144.

Grist, C.L., \& McCord, D.M. (2010). Individual differences in preschool children: Temperament or personality. Infant and Child Development, 19, 264-274.

Grotberg, E.H. (1995). A guide to promoting resilience in children: Strengthening the human spirit (Ed). Bernard van Leer Foundation. Retrieved from https://bibalex.org/baifa/Attac hment/Documents/115519.pdf

Hanson, W.B., Creswell, J.W., Plano Clark, V.L., Petska, K.S., \& Creswell, D. (2005). Mixed methods research designs in counseling psychology. Journal of Counseling Psychology, 52(2), 224-35.

Hart, S., Dixon, A., Drummond, M.J., \& McIntyre, D. (2004). Learning without limits. Maidenhead: Open University Press.

Hattie, J., \& Gan, M. (2011). Instruction based on feedback. In R. Mayer, \& P. Alexander (Eds.), Handbook of research on learning and instruction (pp. 249-271). New York, NY: Routledge.

Herrman, H., Stewart, D.E., Diaz-Granados, N., Berger, E.L., Jackson, B., \& Yuen, T. (2011). What is Resilience? The Canadian Journal of Psychiatry, 56(5), 258-265.

Hjemdal, O. (2007). Measuring protective factors: The development of two resilience scales in Norway. Child and Adolescent Psychiatric Clinics of North America, 16(2),303-321.

Hutchinson, A.K., Stuart, A.D., \& Pretorius, H.G. (2010). Biological contributions to wellbeing: The relationships amongst temperament, character strengths and resilience. Journal of Industrial Psychology, 36(2), 1-10.

Kabasakal, Z., \& Arslan, G. (2014). The relationship between psychological resilience, family problems and antisocial behaviors in adolescence. International Journal of Family, Child and Education, 2(3), 76-90.

Karasar, N. (2012). Bilimsel araştırma yöntemleri. Ankara: Nobel Yayın Dağıtım. 
Kemper, E., Stringfield. S., \& Teddlie, C. (2003). Mixed methods sampling strategies in social science research. In A. Tashakkori, \& C. Teddlie (Eds.), Handbook of mixed methods in social \& behavioral research (pp. 273-296). Thousand Oaks, CA: Sage.

Kim, D.H., \& Im, Y.J. (2014). Resilience as a protective factor for the behavioral problems in school-aged children with atopic dermatitis. Journal of Child Health Care, 18(1), 47-56.

Kochanska, G., \& Knaack, A. (2003). Effortful control as a personality characteristic of young children: Antecedents, correlates, and consequences. Journal of Personality, 71(6), 10871112 .

Lee, P.C., \& Stewart, D.E. (2013). Does a socio-ecological school model promote resilience in primary schools? Journal of School Health, 83(11), 795-804.

Lundman, B., Strandberg, G., Eisemann, M., Gustafson, Y., \& Brulin, C. (2007). Psychometric properties of the Swedish version of the Resilience Scale. Scandinavian Journal of Caring Sciences, 21(2), 229-37.

Luthar, S.S. (1991). Vulnerability and resilience: A study of high-risk adolescents. Child Development, 62(3), 600-616.

Luthar, S.S., Cicchetti, D., \& Becker, B. (2000). The construct of resilience: A critical evaluation and guidelines for future work. Child Development, 71(3), 543-562.

Luthar S.S. (2006). Resilience in development: A synthesis of research across five decades. In: D. Cicchetti, \& D.J., Cohen (Eds.), Developmental psychopathology (2 ${ }^{\text {nd }}$ ed., vol.3: Risk, disorder, and adaptation (pp.739-795). New York: Wiley.

Masten, A.S., Best, K.M., \& Garmezy, N. (1990). Resilience and development: Contributions from the study of children who overcome adversity. Development and Psychopathology, 2(4), 425-444.

Masten, A.S. (1994). Resilience in individual development: Successful adaptation despite risk and adversity: Challenges and prospects. In M. Wang, \& E. Gordon (Eds.), Educational resilience in inner city America: Challenges and prospects (pp. 3-25). Hillsdale, NJ: Lawrence Erlbaum.

Masten, A.S. (2001). Ordinary magic: Resilience processes in development. American Psychologist, 56(3), 227-238.

Masten, A.S., \& Powell, J.L. (2003). A resilience framework for research, policy, and practice. In S.S. Luthar (Ed.) Resilience and vulnerabilities: Adaptation in the context of childhood adversities. New York: Cambridge University Press.

Masten, A.S., Gewirtz, A.H., \& Sapienza, J.K. (2013). Resilience in development: The importance of early childhood. In R.E. Tremblay, R. G. Barr., \& R. DeV. Peters (Eds.), Encyclopedia on early childhood development [online]. Retrieved from http://www.child-encyclopedia.com/sites/default/files/textes-experts/en/834/resiliencein-development-the-importance-of-early-childhood.pdf

Masten, A.S. (2015). Pathways to integrated resilience science. Psychological Inquiry, 26(2), $187-196$.

Metin, İ. (2010). The effects of dispositional anger, effortful control and maternal responsiveness on turkish preschoolers' emotion regulation (Unpublished master's thesis). Koç Üniversitesi Sosyal Bilimler Enstitüsü, İstanbul.

Miljević-Riđički, R., Bouillet, D., \& Cefai, C. (2013). Pre-curriculum activities: Focus groups on resilience. In Bertram, T., Formosinho, J., Lohmander, M.K., Veisson, M., Ugaste, A., Õun, T., Tuuling, L. (Eds.), Abstract Book of the Value, Culture and Contexts 23rd Annual ECERA Conference (p.52), Tallinn University, Tallinn. Retrieved from: https:/www.eecera.org/wp-content/uploads/2013/08/2013-tallinn.pdf

Miljević-Riđički, R., Plantak, K., \& Bouillet, D. (2017). Resilience in preschool children-the perspectives of teachers, parents and children. International Journal of Emotional Education, 9(2), 31-43. 
Miller-Lewis, L.R., Searle, A. K., Sawyer, M.G., Baghurst, P.A., \& Hedley, D. (2013). Resource factors for mental health resilience in early childhood: An analysis with Multiple methodologies. Child and Adolescent Psychiatry and Mental Health, 7(6), 1-23.

Miles, M.B., Huberman, A.M., \& Saldana, J. (2014). Qualitative data analysis: A methods sourcebook and the coding manual for qualitative researchers ( $3 \mathrm{rd}$ ed.). Thousand Oaks, CA: Sage Publications.

Morse, J.M. (2003). Principles of mixed methods and multimethod research design. In A. Tashakkori, \& C. Teddlie. (Eds.), Handbook of mixed methods in social and behavioral research (pp. 189-208). Thousand Oaks, CA: Sage Publications.

Nasvytiene, D., Lazdauskas, T., \& Leonavičiene, T. (2012). Child's resilience in face of maltreatment: A meta-analysis of empirical studies. Psichologija, 46, 7-26.

Nolan, A., Taket, A., \& Stagnitti, K. (2014). Supporting resilience in early years classrooms: The role of the teacher. Teachers and Teaching: Theory and Practice, 20(5), 595-608.

Oades-Sese, G.V., \& Esquivel, G.B. (2006). Resilience among at-risk Hispanic American preschool children. Annals of the New York Academy of Sciences, 1094(1), 335-339.

Ogelman, H.G. (2015). Predictor effect of parental acceptance-rejection levels on resilience of preschool children. Social and Behavioral Sciences, 174, 622-628.

Oldehinkel, A.J., Hartman, C., DeWinter, A.F., Veenstra, R., \& Ormel, J. (2004). Temperament profiles associated with internalizing and externalizing problems in preadolescence. Development and Psychopathology, 16(2), 421-440.

Oswald, M., Johnson, B., \& Howard, S. (2003). Quantifying and evaluating resiliencepromoting factors: Teachers' beliefs and perceived roles. Research in Education, 70(1), 50-64.

Önder, A., Dağal, A. B., \& Bayındır, D. (2018). The predictive effect of preschool children's temperament characteristics and parenting styles of mothers on ego resiliency level of children. Education \& Science, 43(193), 79-90.

Prior, M., Sanson, A., \& Oberklaid, F. (1989). The Australian Temperament Project. In G.A. Kohnstammve J.E. Bates, \& M.K. Rothbart (Eds.), Temperament in childhood (pp. 537556). Chichester: John Wiley and Sons.

Prior, M., Bavin, E., Cini, E., Eadie, P., \& Reilly, S. (2011). Relationships between Language Impairment, Temperament, Behavioural Adjustment and Maternal Factors in A Community Sample of Preschool Children. International Journal of Language \& Communication Disorders, 46(4), 489-494.

Reed-Victor, E., \& Stronge, J. H. (2002). Homeless students and resilience: Staff perspectives on individual and environmental factors. Journal of Children Poverty, 8(2), 159-183.

Resnick, M.D., \& Taliaferro, L.A. (2011). Resilience. In B. Bradford Brown \& M. Prinstein (Eds.), Encyclopedia of adolescence (pp. 299-306). San Diego, CA: Academic Press.

Rothbart, M.K., \& Bates, J.E. (2006). Temperament. In W. Damon, R.M. Lerner., \& N. Eisenberg (Eds.), Handbook of child psychology, Six edition: Social, emotional, and personality development (pp. 99-166). New York: John Wiley \& Sons Inc.

Rothbart, M.K. (2011). Becoming who we are: Temperament and personality in development. New York, NY: The Guilford Press.

Rutter, M. (1987). Psychosocial resilience and protective mechanisms. American Journal of Orthopsychiatry, 57, 316-331.

Sanson, A., \& Rothbart, M.K. (1995). Child temperament and parenting. In M. Bornstein (Ed.), Handbook of Parenting (Vol:4, pp. 299-321). Hillsade, NJ: Erlbaum.

Sanson, A., Hemphill, S.A., \& Smart, D. (2004). Connections between temperament and social development: A review. Social Development, 13, 142-170.

Sattler, K.M.P., \& Font, S.A. (2018). Resilience in young children involved with child protective services. Child Abuse \& Neglect, 75, 104-114. 
Smith, J., \& Prior, M. (1995). Temperament and stress resilience in school-age children: A within-families study. Journal of the American Academy of Child \& Adolescent Psychiatry, 34(2), 168-179.

Spinrad, T.L., Eisenberg, N., Gaertner, B., Popp, T., Smith, C.L., Kupfer, A., Greving, K., Liew, J., \& Hofer, C. (2007). Relations of maternal socialization and toddlers' effortful control to children's adjustment and social competence. Developmental Psychology, 43(5), $1170-1186$.

Sun, J., \& Stewart, D. (2007). Age and gender effects on resilience in children and adolescents. International Journal of Mental Health Promotion, 9(4), 16-25.

Taylor, Z.E., Eisenberg, N., Spinrad, T.L., \& Widaman, K.F. (2013). Longitudinal relations of intrusive parenting and effortful control to ego-resiliency during early childhood, Child Development, 84(4), 1145-1151.

Thomas, A., \& Chess, S. (1977). Temperament and development. New York: Brunner/Mazel.

Ungar, M., Brown, M., Liebenberg, L., Othman, R., Kwong, W.M., Armstrong, M., \& Gilgun, J. (2007). Unique pathways to resilience across cultures. Adolescence, 42(166), 287-310.

Ungar, M. (2011). The social ecology of resilience: Addressing contextual and cultural ambiguity of a nascent construct. American Journal of Orthopsychiatry, 81(1), 1-17.

Ungar, M. (Ed.) (2012). The social ecology of resilience: A handbook of theory and practice. New York, NY: Springer.

Ungar, M. (2013). Resilience after maltreatment: The importance of social services as facilitators of positive adaptation. Child Abuse \& Neglect, 37(2-3), 110-115.

Wright, M.O.D., Masten, A.S., \& Narayan, A.J. (2013). Resilience processes in development: Four waves of research on positive adaptation in the context of adversity. In S. Goldstein \& R. B. Brooks, Handbook of resilience in children (2nd ed., pp. 15-37). New York, NY: Springer.

Yıldırım, A., \& Şimşek, H. (2013). Sosyal bilimlerde nitel araştırma yöntemleri. Ankara: Seçkin Yayınları.

Yağmurlu. N., Sanson. A., \& Köymen. B. (2005). Effects of parenting and child temperament on the development of prosocial behavior: The mediating role of theory of mind. Turkish Journal of Psychology, 20(55), 1-20.

Yağmurlu, B., \& Sanson, A. (2009). Parenting and temperament as predictors of prosocial behavior in Australian and Turkish Australian children. Australian Journal of Psychology, 61, 77-88.

Yağmurlu, B., \& Kodalak, A.C. (2010). Bağlanma, mizaç ve ebeveyn-çocuk ilişkileri [Attachment, temperament and parent-child relationships]. (T. Solmuş (Ed.), Bağlanma, Evlilik ve Aile Psikolojisi içinde [In attachment, marriage and family psychology], (111125). İstanbul: Sistem.

Yoleri, S. (2014). The relationship between temperament, gender, and behavioural problems in preschool children. South African Journal of Education, 34(2), 1-18. 